\title{
DISTRIBUSI THERMAL FRONTDAN HASIL TANGKAPAN IKAN TENGGIRI (Scomberomorus commerson) DI PERAIRAN PANGANDARAN
}

\author{
Distribution of Thermal front and Catches of Mackerel Fish (Scomberomorus commerson) in \\ Pangandaran Waters
}

Oleh:

Vadhilah Savetri ${ }^{1}$, Mega Laksmini Syamsuddin ${ }^{2}$, Iis Rostini ${ }^{2}$, dan Izza Mahdiana Apriliani $^{2}$

${ }^{1}$ Prodi Perikanan Fakultas Perikanan dan Ilmu Kelautan Universitas Padjadjaran

${ }^{2}$ Fakultas Perikanan dan Ilmu Kelautan Universitas Padjadjaran

Korespondensi:dhilbed@gmail.com

\begin{abstract}
ABSTRAK
Ikan tenggiri (Scomberomorus commerson) merupakan komoditas ikan pelagis besar unggulan di Kabupaten Pangandaran karena memiliki jumlah dan nilai produksi yang paling tinggi, oleh karena itu perlu dimanfaatkan secara maksimal dengan memperhatikan kelestariannya. Tujuan dari riset ini adalah untuk mengetahui variabilitas thermal front secara spasial dan temporal serta pengaruhnya terhadap hasil tangkapan ikan tenggiri dalam pendugaan daerah penangkapan potensial ikan di peraira Pangandaran, Jawa Barat. Riset ini dilaksanakan pada bulan Januari sampai dengan bulan Februari 2018 di Perairan Pangandaran, Jawa Barat. Data yang digunakan pada penelitian ini adalah SPL yang berasal dari AquaMODIS dan arus geostrofik dari ECMWF. Metode yang digunakan adalah metode deskriptif dengan pendekatan analisis secara spasial dan temporal. Thermal front dideteksi pada data citra raster suhu permukaan laut (SPL) menggunakan algoritma Cayulla Cornilon 1992 dengan kategori kuat dengan perbedaan $\mathrm{SPL} \geq 0,5^{\circ} \mathrm{C}$ dan lemah dengan perbedaan SPL $0,3^{\circ} \mathrm{C}$. Hasil riset menunjukan front yang terbentuk di perairan Pangandaran merupakan front sementara dengan kekuatan lemah dan kuat. Sebaran dan frekuensi thermal front paling banyak ditemukan pada bulan Desember (musim barat) dengan total 11 unit kemunculan dengan nilai rata-rata SPL $29,3^{\circ} \mathrm{C}$ dan sebaran paling sedikit dijumpai pada bulan April (musim peralihan 1). Kisaran suhu tertinggi thermal front berkisar antara $30-33,8^{\circ} \mathrm{C}$ dan terendah berkisar antara $22,8-26,5^{\circ} \mathrm{C}$. Kejadian thermal front umumnya terjadi di perairan lepas Samudera Hindia.
\end{abstract}

Kata kunci: arus, ikan tenggiri, perairan Pangandaran, SPL, thermal front

\begin{abstract}
Mackerel fish (Scomberomorus commerson) is a superior large pelagic commodity in Pangandaran Regency because it has the highest number of production quantities and values, and therefore needs to be utilized to the fullest with due regard to its sustainability. The purpose of this research is to determine the spatial and temporal variability of the thermal front and its effect on the catch of mackerel in estimating potential fishing areas in Pangandaran waters, West Java. This research were conducted from January to February 2018 in Pangandaran waters, West Java. The data used in this study are SPL derived from AquaMODIS and geostrophic flow from ECMWF. The method used is a descriptive method with a spatial and temporal analysis approach. Thermal front was detected in the sea surface temperature (SPL) raster image data using the Cayulla Cornilon 1992 algorithm with a strong category with a difference of $S P L \geq 0.5^{\circ} \mathrm{C}$ and weak with a $S P L$ difference of $0.3^{\circ} \mathrm{C}$. Research results show that the front formed in Pangandaran waters is a temporary front with weak and strong
\end{abstract}


strengths. The most common distribution and frequency of thermal fronts were found in December (west season) with a total of 11 units occurring with an average $S P L$ value of $29.3^{\circ} \mathrm{C}$ and the least distribution was found in April (transition season 1). The highest temperature range of the thermal front is between $30-33.8^{\circ} \mathrm{C}$ and the lowest is in the range of $22.8-26.5^{\circ} \mathrm{C}$. Thermal front events generally occur in waters off the Indian Ocean.

Key words: current, mackerel fish, Pangandaran waters, SST, and thermal front

\section{PENDAHULUAN}

Salah satu Wilayah Pengelolaan Perikanan (WPP) 573 Samudera Hindia yang mencakup perairan ujung barat pulau Sumatera dan pantai selatan Jawa dan Pangandaran merupakan salah satu wilayah yang termasuk dalam WPP tersebut. Sektor tersebut memberikan kotribusi besar bagi pereonomian daerah dan masyarakat di wilayah itu (Nurhayati 2013).

Ikan tenggiri merupakan hasil tangkapan ikan pelagis besar unggulan WPP 573 yang juga didaratkan di perairan Kabupaten Pangandaran. Ikan tenggiri merupakan komoditas ikan pelagis besar unggulan di Kabupaten Pangandaran karena tersedia sepanjang tahun dan memiliki nilai ekonomis yang tinggi. Berdasarkan data statistik Dinas Kelautan dan Perikanan Provinsi Jawa Barat dari tahun 2005-2014 ikan tenggiri di Kabupaten Pangandaran memiliki jumlah produksi sebesar 861,24 ton dengan nilai produksi sebesar Rp19.222.709.000,00. Oleh karena itu ikan tenggiri perlu dimanfaatkan secara maksimal dengan memperhatikan kelestariannya agar dapat dimanfaatkan secara berkelanjutan.

Perairan Indonesia merupakan perairan yang terletak diantara Samudera Pasifik dan Hindia. Massa air dari Pasifik masuk dan menyebar di perairan Indonesia sebelum mengalir keluar Indonesia. Front merupakan salah satu proses oseanografi yang berpengaruh terhadap kondisi fisika dan biolo suatu perairan. Olson (1994) terdapat banyak variasi kemungkinan front, yaitu thermal front, salinitas front, klorofil-a front. Thermal front adalah front yang dideteksi dari suhu permukaan laut. Thermal front merupakan proses oseanografi yang mempengaruhi kelimpahan dan distribusi ikan. Thermal front terjadi karena pertemuan dua massa air yang berbeda (Angraeni et al, 2014). Secara umum thermal front dapat ditemukan di perairan pesisir. Hal ini dikarenakan hempasan massa air dari daratan mempunyai suhu berbeda dengan suhu air air laut, sehingga terbentuklah thermal front.

Front biasanya berasosiai dengan kemunculan upwelling. Upwelling adalah proses penaikan massa air dari bawah ke permukaan yang biasanya membawa nutrien. Lokasi front yang diikuti oleh melimpahnya klorofil-a dapat mengarah pada terjadinya upwelling. Menurut Wyktri (1962), Susanto, et al. (2001), Hendrianti et al. (2005), wilayah potensial upwelling yang terjadi di perairan Indonesia adalah Samudera Hindia Barat Sumatera, Selatan Jawa Bali Nusa Tenggara, Selat Makassar, Laut Banda, serta Laut Arafura.

SIED (Single Image Edge Detection) merupakan salah satu metode otomatis identifikasi thermal front yang dikembangkan oleh Cayulla dan Cornillon (1992). Dalam penginderaan jauh metode ini termasuk dalam deteksi tepi. Deteksi tepi (edge detection) adalah pemrosesan citra yang menghasilkan tepi-tepi dari obyek-pbyek citra, tujuannya adalah untuk memperjelas bagian yang ingin didetailkan dalam citra atau untuk memperbaiki detail citra yang kabur akibat eror dari proses akuisisi citra. Hamzah et al. (2014) menyatakan bahwa penentuan front menggunakan metode SIED secara otomatis mampu mendeteksi front di seluruh luasan citra yang dianalisis dan dibandingkan dengan metode visual. Podesta et al. (1993) menerapkan metode ini di Barat Laut Atlantik.

Tujuan dari riset ini untuk mengetahui variabilitas thermal front secara spasial dan temporal di perairan Pangandaran, Jawa Barat. Hasil analisis jumlah kejadian front yang terbentuk diharapkan dapat menemukan daerah yang mengalami kejadian front paling banyak sebagai salah satu prediksi daerah dengan tingkat kesuburan tinggi. Dengan tingkat kesuburan yang tinggi tersebut maka dapat 
diprediksi juga bahwa tempat tersebut mempunyai lingkungan perairan yang disukai dan cocok bagi habitat fitoplankton ataupun organisme perairan lainnya untuk dijadikan sebagai wilayah yang baik untuk penangkapan ikan.

\section{METODE PENELITIAN}

Riset ini dilaksanakan dalam dua tahap. Tahap pertama adalah tahap pengumpulan data di perairan Pagandaran, fishing base Pelabuhan Pendaratan Ikan (PPI) Pangandaran yang dilaksanakan pada bulan Januari-Februari 2019. Tahap kedua adalah pengolahan data.

Metode riset yang digunakan yaitu dengan metode survei yang meliputi pengumpulan data lapangan (in-situ) dan analisis visual citra (ex-situ). Data in-situ merupakan data lapangan yang meliputi waktu operasi penangkapan, posisi penangkapan, dan produksi penangkapan ikan tenggiri diperoleh dari Pelabuhan Pendaratan Ikan Pangandaran. Data ex-situ berupa arus dan dan citra suhu diperoleh dari citra satelit yang telah terdeteksi. Selain itu, untuk validasi data posisi penangkapan ikan yang diperoleh, maka dilakukan wawancara dengan beberapa nelayan.

Data yang digunakan dalam riset ini adalah data sekunder meliputi data produksi ikan tenggiri, lokasi penangkapan, arus, dan SPL. Data yang digunakan berupa time series selama tiga tahun dari Januari 2016-Desember 2018. Armada penangkapan yang digunakan dalam pengambilan data produksi dan posisi penangkapan adalah gill net dengan ukuran kapan 2-3 GT dengan operasi one day trip.

Analisis thermal front dilakukan dengan mengambil data bulanan dengan periode yang sama dengan periode data tangkapan ikan tenggiri. Data diperoleh dari sensor MODIS aqua dengan resolusi spasial $4 \mathrm{Km}$. Data input yang digunakan untuk proses deteksi thermal front, yaitu data SPL dari hasil pengolahan ataupun hasil pengolahan otomatis.

Data pola arus dan deteksi thermal front secara spasial disatukan (overlay) dengan titik koordinat penangkapan. Hasil data tersebut kemudian dianalisis secara deskriptif untuk melihat keterkaitan arus, thermal front serta posisi penangkapan dan hasil tangkapan di Perairan Pangandaran.

\section{HASIL DAN PEMBAHASAN}

Variabilitas Suhu Permukaan Laut (SPL) Perairan Pangandaran menunjukkan perbedaan sesuai perubahan musim. Perbedaan secara temporal fluktuasi nilai SPL di perairan Pangandaran berkisar antara $27,1-31,03^{\circ} \mathrm{C}$. Nilai SPL tahun 2016 terendah terjadi pada bulan Agustus dengan nilai $28,96^{\circ} \mathrm{C}$ sedangkan nilai SPL tertinggi terjadi pada bulan Maret dengan nilai $31,03^{\circ} \mathrm{C}$. Nilai SPL tertinggi terjadi lagi pada bulan Maret Tahun 2017 dengan nilai $30.02^{\circ} \mathrm{C}$ dan nilai SPL terendah dengan nilai $27,34^{\circ} \mathrm{C}$ terjadi pada Bulan Agustus. Berbeda dengan dua tahun sebelumnya, nilai SPL tertinggi pada tahun 2018 terjadi pada Bulan April dengan nilai $30,04^{\circ} \mathrm{C}$ sedangkan SPL terendah terjadi pada Bulan September dengan nilai $27,23^{\circ} \mathrm{C}$. Rata-rata nilai SPL selama tiga tahun di perairan Pangandaran, yaitu sebesar $29,2^{\circ} \mathrm{C}$.

Nilai SPL yang variatif dalam tiga tahun di perairan Pangandaran oleh pola pergerakan dan kecepatan angin monsoon. Angin monsoon menyebabkan Indonesia mengenal Musim Barat dan Musim Timur yang berpengaruh di darat maupun perairan Indonesia. 


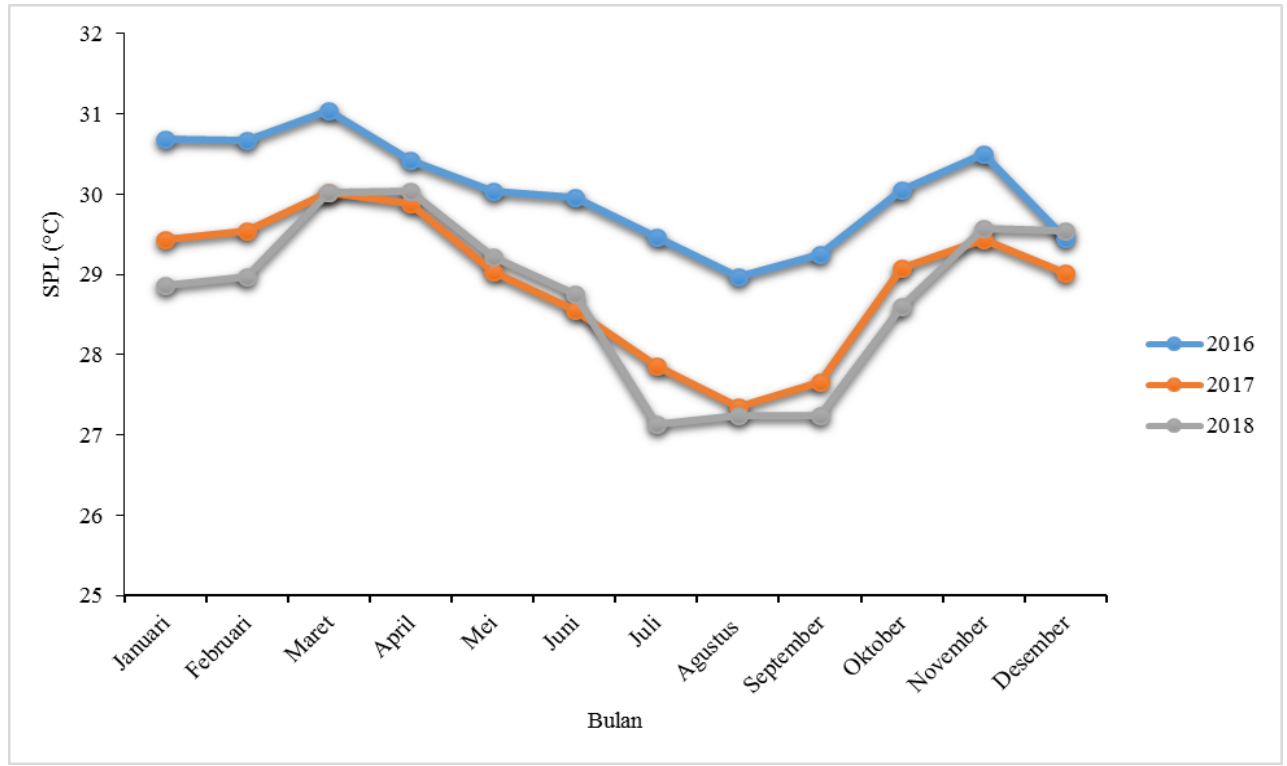

Gambar 1 Variabilitas SPL di perairan Pangandaran

Hasil pengolahan data arus geostropik di perairan Pangandaran pada tahun 2016-2018 memiliki kecepatan yang bervariasi (Gambar 2). Rata-rata kecepatan arus berkisar antara 0,6-7,3 m/detik. Hasil analisis deret waktu pada grafik (Gambar 2) menunjukan terjadinya tren kecepatan arus yang meningkat dari tahun ke tahun. Arus dengan kecepatan terendah terjadi pada bulan Januari 2016 sedangkan untuk kecepatan tertinggi terjadi pada bulan Juli 2017. Adanya anomali arus diduga karena adanya pengaruh musim. Kecepatan arus tertinggi pada tahun 2016 terjadi di bulan Agustus dengan nilai $4,9 \mathrm{~m} / \mathrm{s}$ dan terendah terjadi di bulan Januari dengan nilai $0,66 \mathrm{~m} / \mathrm{s}$. Bulan Juli tahun 2017 kecepatan arus tertinggi mencapai 7,31 m/s sedangkan kecepatan terendahnya $1,72 \mathrm{~m} / \mathrm{s}$ yang terjadi pada bulan Maret. Tahun 2018 kecepatan arus tertinggi terjadi lagi di bulan Agustus dengan nilai 6,69 $\mathrm{m} / \mathrm{s}$ dan terendahnya dengan nilai $1,37 \mathrm{~m} / \mathrm{s}$ yang terjadi pada Bulan Maret.

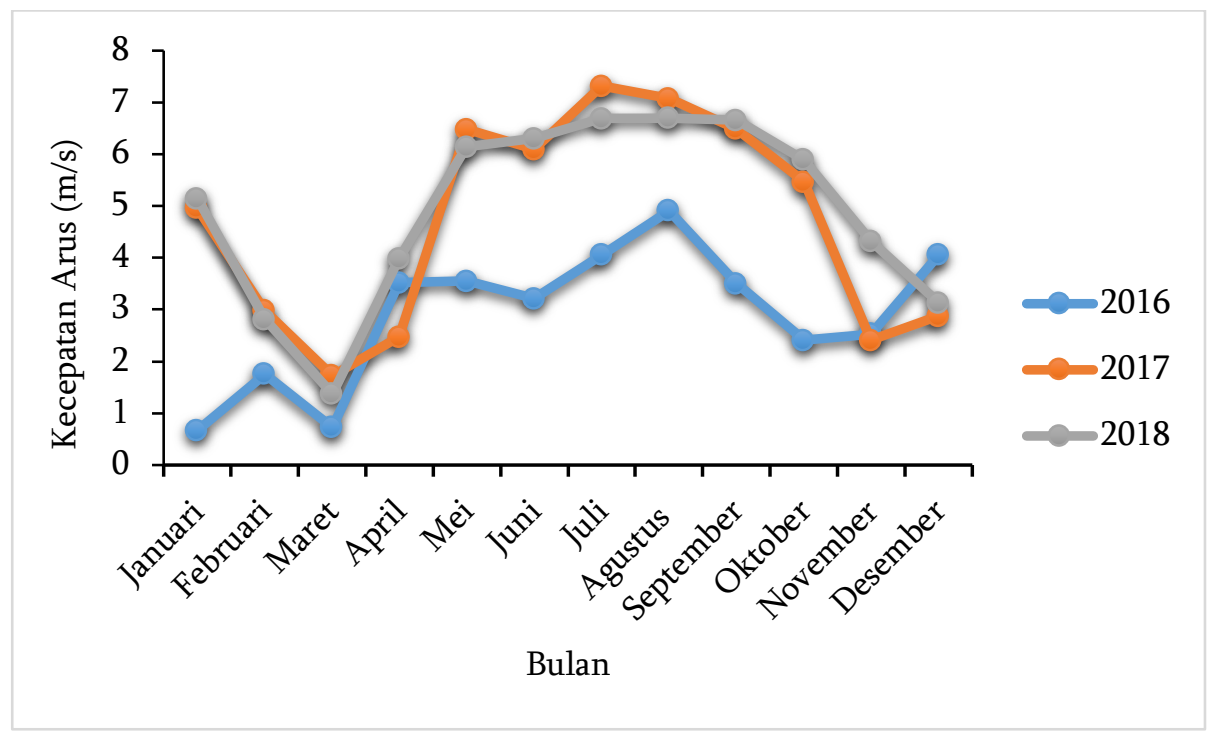

Gambar 2 Variabilitas arus di perairan Pangandaran

Berdasarkan hasil analisis anatara SPL dan arus, menunjukan bahwa arus mempengaruhi SPL rata-rata di perairan Pangandaran. Dimana pada saat kecepatan arus permukaan meningkat SPL mengalami penurunan suhu, begitu juga terjadi sebaliknya. SPL perairan Pangandaran pada umumnya dipengaruhi oleh fluktuasi musiman yang terjadi sepanjang Selatan Perairan Jawa hingga Sumbawa. 
Pola thermal front yang terbentuk pada tahun 2016 terdiri dari weak front (garis hitam) dan strong front (garis merah). Umumnya thermal front terbentuk di wilayah selatan Pangandaran dan bersifat tidak tetap (sementara). Berdasarkan analisis visual, thermal front dengan intensitas kuat terbentuk pada musim peralihan 2 dan musim barat, dengan puncak terbentuknya pada bulan November yang ditandai dengan garis berwarna merah. Sedangkan pada musim peralihan 1 thermal front yang terbentuk merupakan weak front. Memasuki bulan Oktober intensitas terbentuknya thermal front mulai meningkat dengan intensitas kekuatannya weak front diduga akibat efek peralihan dari musim timur ke musim peralihan 2. Kondisi suhu perairan bulan September menujukkan $29,3^{\circ} \mathrm{C}$ dan memperlihatkan massa air yang cukup hangat sampai dengan Bulan Desember $\left(29,5^{\circ} \mathrm{C}\right)$. Hal ini diduga merupakan bagian dari Arlindo. Sebagaimana diketahui bahwa aliran massa air dari Samudera Pasifik ke Samudera Hindia melewati sebagian besar laut di Indonesia yang melewati perairan di barat Sumatera.
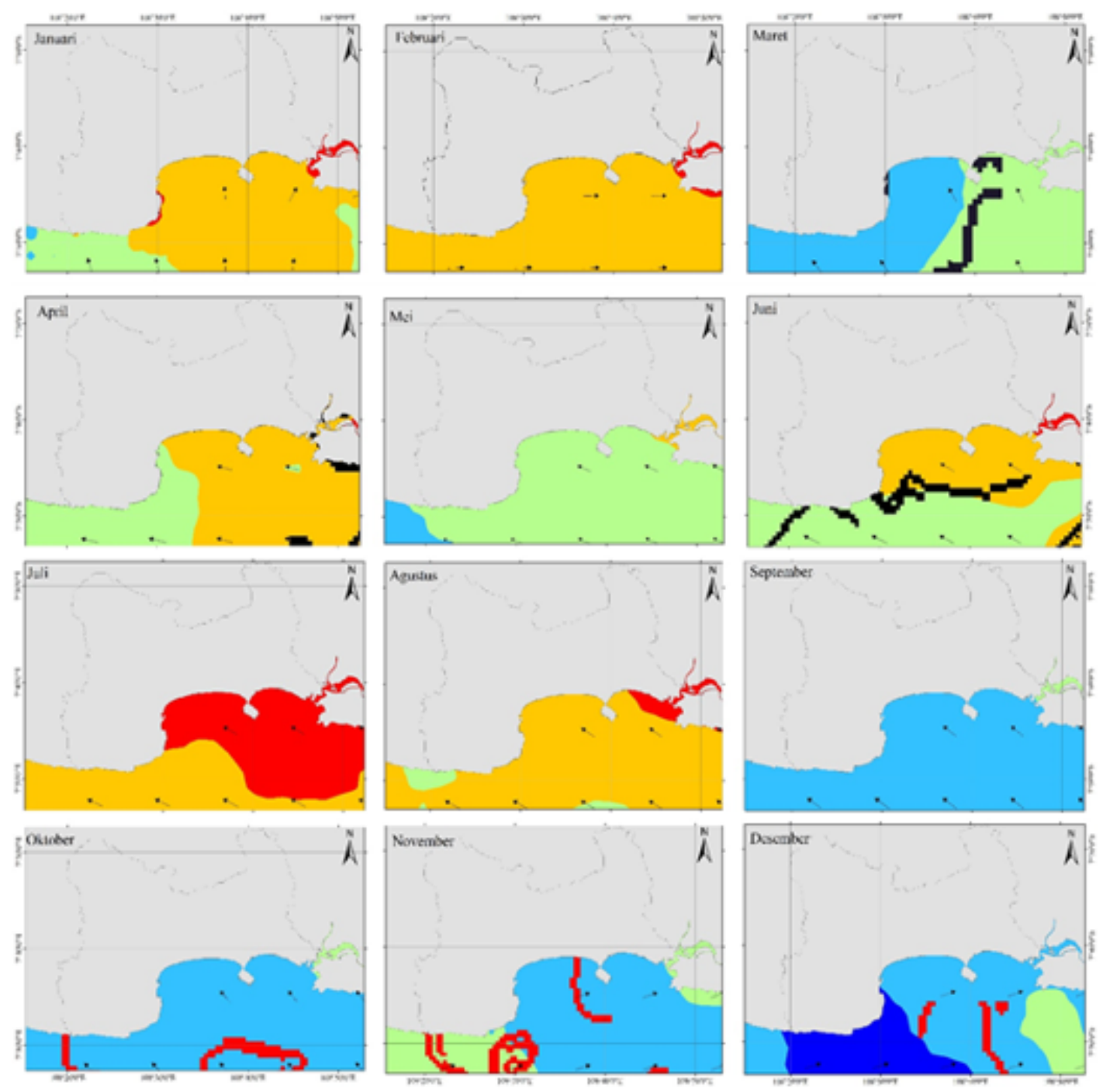

SPL $\left({ }^{\circ} \mathrm{C}\right)$

$\begin{array}{lllllllllllll}23 & 24 & 25 & 26 & 27 & 28 & 29 & 30 & 31 & 32 & 33 & 34 & 35\end{array}$

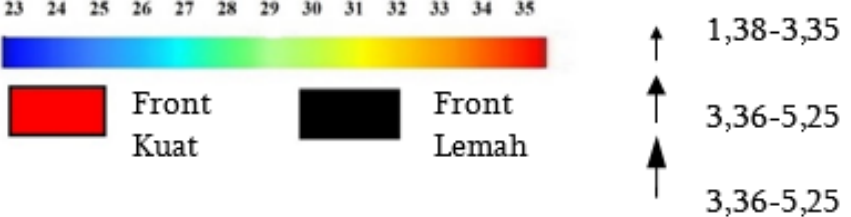

Kecepatan arus (m/s)

$3,36-5,25$

Gambar 3 Thermal front tahun 2016 
Arus yang terbentuk pada tahun 2016 cukup bervariatif, musim timur merupakan arus yang mecapai kecepatan tertinggi dengan nilai $6,38 \mathrm{~m} / \mathrm{s}$, sedangkan untuk kecepatan arus terendah terjadi pada musim peralihan 1 dengan nilai $0,01 \mathrm{~m} / \mathrm{s}$.

Secara spasial pergerakan SPL dengan massa air hangat cenderung bergerak dari Samudera Hindia. Musim peralihan (barat-timur) terlihat perbedaan pergerakan SPL dengan musim barat. Pada musim ini sebaran SPL menunjukkan telah bercampur antara massa air hangat dan massa air dingin, diduga hal terjadi karena perubahan pola pergerakan angin musim yang mendorong massa air permukaan. Front yang berulang pada wilayah yang sama terjadi pada bulan Desember, namun thermal front yang terbentuk merupakan weak front. Kecepatan arus maksimum yang terjadi di tahun 2017 konstan terjadi pada musim timur mencapai $9,88 \mathrm{~m} / \mathrm{s}$, sedangkan arus minimum terjadi lagi pada musim peralihan 1 dengan nilai $0,25 \mathrm{~m} / \mathrm{s}$.
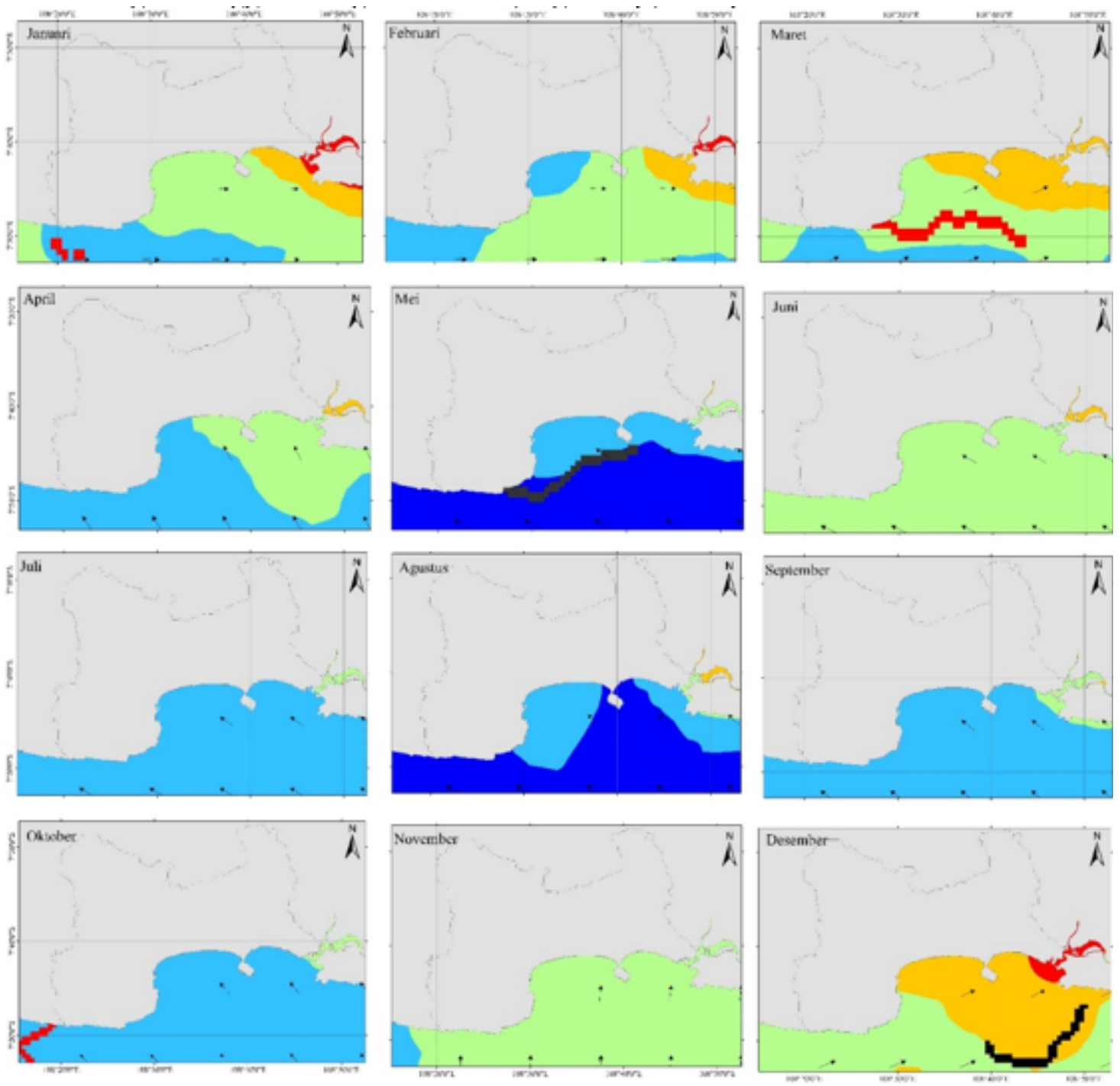

SPL $\left({ }^{\circ} \mathrm{C}\right)$

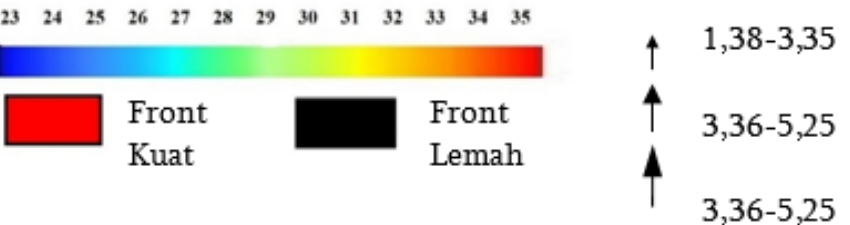

Kecepatan $\operatorname{arus}(\mathrm{m} / \mathrm{s})$

$3,36-5,25$

Gambar 4 Thermal front tahun 2017 
Menurut Hanintyo et al. (2015) jumlah kejadian thermal front pada perairan Laut Banda, Laut Maluku, dan Laut Sulawesi cenderung lebih banyak terdapat pada kawasan perairan pesisir. Hempasan air dari daratan dengan karakteristik suhu yang berbeda dibandingkan dengan SPL menyebabkan terjadinya front. Sedangkan, hasil riset ini menunjukkan bahwa perairan Pangandaran yang mendekati dengan teluk memiliki jumlah kejadian thermal front lebih banyak dibandingkan pada kawasan baratnya.

Daulay (2019) meneliti pembentukan thermal front di perairan tropis Samudera Hindia bagian timur dengan gradien suhu yang digunakan adalah $0,5^{\circ} \mathrm{C}$ dan suhu thermal front berkisar antara 26,4$32^{\circ} \mathrm{C}$ terjadi pada perairan bagian pesisir dan perairan lepas Samudera Hindia dengan suhu terendah thermal front terjadi pada bulan September. Sedikit berbeda dengan riset tersebut sebelumnya, perairan Pangandaran memiliki suhu thermal front berkisar antara $25,8-34^{\circ} \mathrm{C}$ dengan suhu terendah thermal front terjadi pada bulan Mei dengan menggunakan gradien suhu yang sama, yaitu $0,5^{\circ} \mathrm{C}$.

Hasil analisis deteksi thermal front pada tahun 2018 menunjukan adanya fluktuasi terbentuknya thermal front secara spasial dan temporal. Thermal front yang terbentuk pada musim barat ini akibat adanya kantung-kantung massa air yang terbentuk berdasarkan perbedaan SPL di sekelilingnya. Adanya kantung-kantung massa air yang lebih hangat dibandingkan perairan sekitar berkumpul pada daerah selatan Pangandaran sehingga dapat menyembabkan thermal front dengan perbedaan suhu yang relatif besar. Pergerakan SPL pada musim barat (Desember, Januari, dan Februari) secara visual menunjukkan suhu panas $\left(33,0-34,9^{\circ} \mathrm{C}\right)$ tepat di perairan Pangandaran. Hal ini disebabkan karena masih berpengaruhnya SPL pada musim peralihan 2 yang cenderung hangat.

Hal tersebut sesuai dengan pernyataan Wyrtki (1961) dalam Hanintyo et al. (2015) bahwa selama angin musim barat berhembus maka curah hujan akan meningkat dan air sungai banyak yang masuk ke laut, sehingga menyebabkan pengenceran terhadap air laut, dan sebaliknya selama angin musim timur. Pada musim barat, curah hujan yang terjadi akan lebih tinggi, sehingga hempasan air dari daratan juga akan mempunyai suhu yang cukup berbeda dari biasanya, sehingga kemungkinan perbedaan suhu saat mencapai lautan akan mengakibatkan pembentukan front, maka pada musim barat thermal front yang terbentuk akan lebih banyak dibandingkan dengan musim timur.

Arus yang terjadi pada musim barat tahun 2018 di perairan Pangandaran memiliki kecepatan rata-rata 1,3 sampai 7,00 m/s mengalir dari barat menuju timur, arus tersebut berasal dari perairan barat jawa hingga ke timur perairan jawa. Arah arus yang dominan menuju ke arah timur diduga merupakan Arus Pantai Jawa (APJ), hal ini sesuai dengan pernyataan Wyrtki (1961) dalam Safitri et al. (2012), APJ berkembang pada musim barat, arah arusnya mengalir dari barat menuju timur. Tahun 2018 arus dengan kecepatan maksimum terjadi lagi pada musim timur dengan nilai mecapau 9,37 m/s. Musim peralihan 1 memiliki nilai kecepatan minimum, yaitu $0,36 \mathrm{~m} / \mathrm{s}$.

Berdasarkan data produksi ikan tenggiri selama tiga tahun (2016-2018), umumnya hampir disetiap bulan ikan tenggiri ditangkap terutama pada musim barat, walaupun ada lonjakan cukup tinggi pada bulan Agustus tahun 2017 dengan jumlah produksi sekitar 25 ton. Hail tangkapan ikan tenggiri pada musim barat selama 3 tahun merupakan tangkapan tertinggi diantara musim yang lainnya (Gambar 6). Hal ini ditandai dengan jumlah produksi tertinggi terjadi pada musim bulan Desember, Januari, Februari yang merupakan musim barat. 

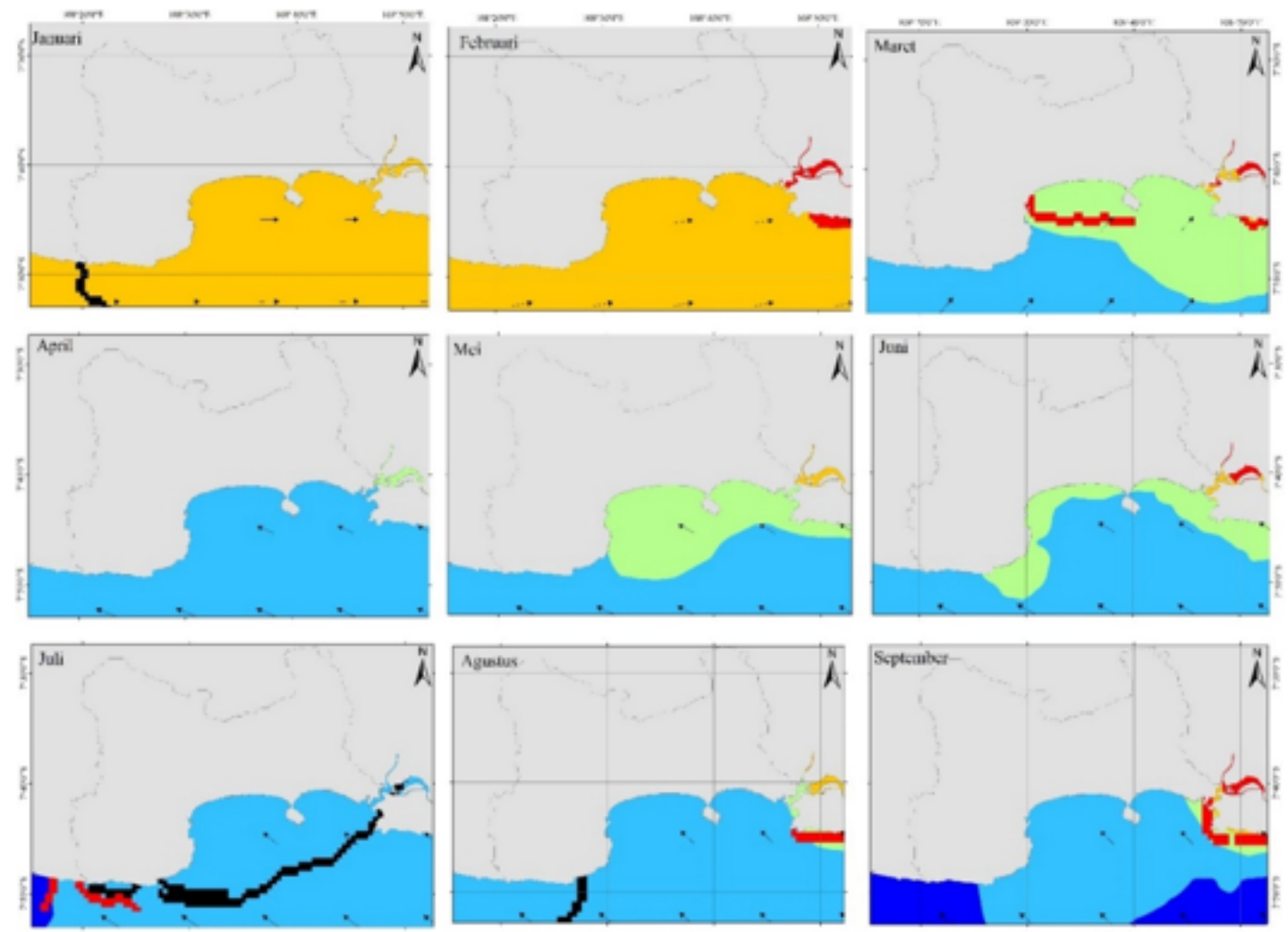

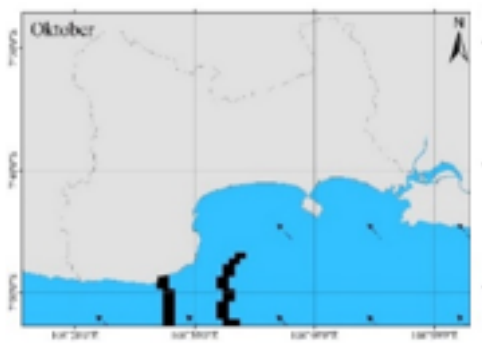

SPL $\left({ }^{\circ} \mathrm{C}\right)$

$\begin{array}{lllllllllllll}23 & 24 & 25 & 26 & 27 & 28 & 29 & 30 & 31 & 32 & 33 & 34 & 35\end{array}$

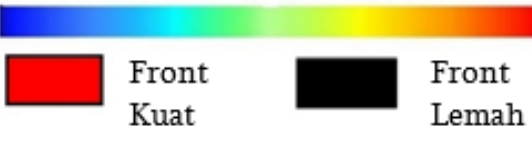

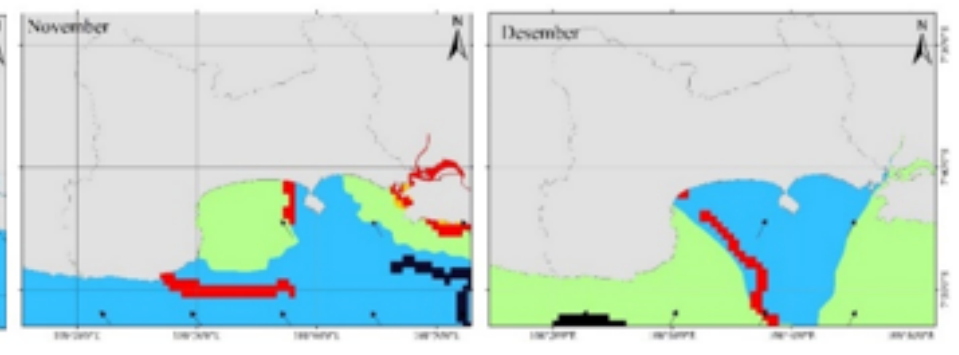

Kecepatan arus (m/s)

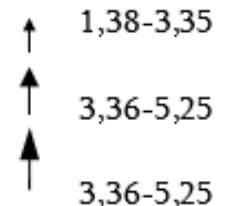

Gambar 5 Thermal front tahun 2018

Secara umum jika dilihat dari hasil tangkapan, musim barat merupakan musim dengan hasil tangkapan tertinggi. Menurut Situmorang (2017) variasi iklim musim mempengaruhi ketersediaan sumberdaya sehingga menyebabkan terjadinya fluktuasi produksi karena aktivitas penangkapan tergantung keberadaan ikan. Hal ini dikarenakan distribusi ikan tenggiri dipengaruhi oleh kondisi oseanografi secara spasial maupun temporal. Indikator perubahan iklim dapat dilihat dengan bergesernya periode musim dari waktu biasanya. 


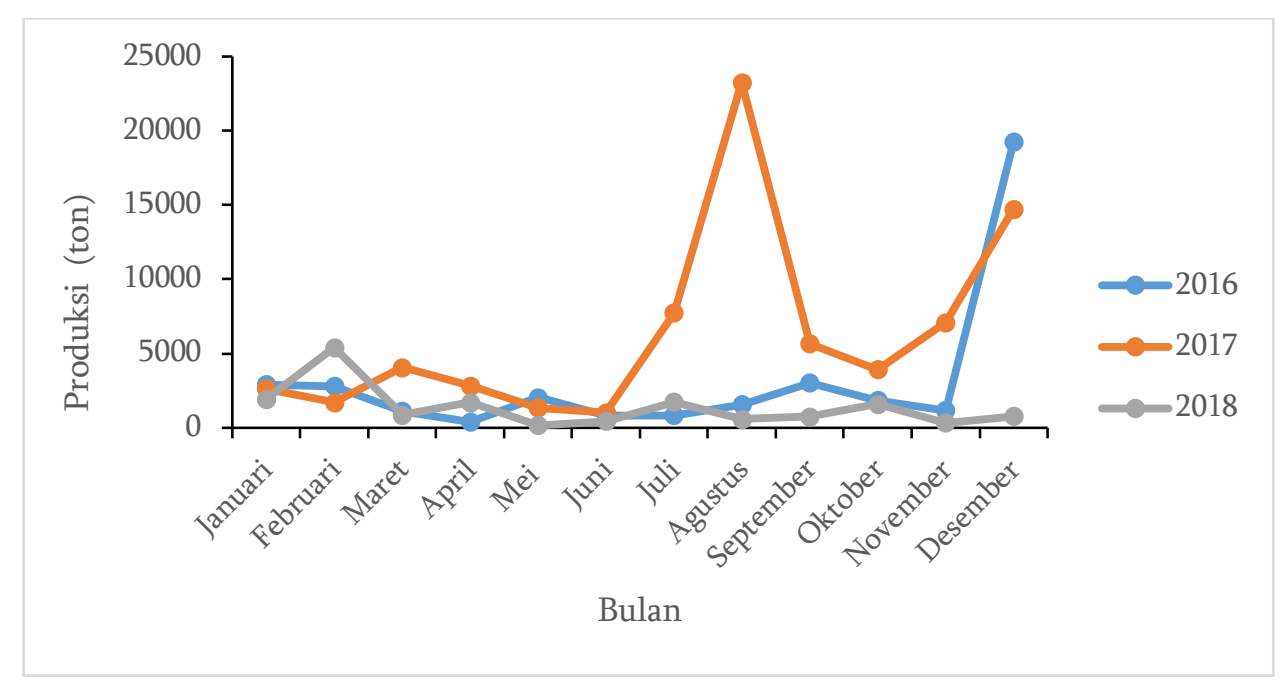

Gambar 6 Produksi hasil tangkapan ikan tenggiri tahun 2016-2018

Thermal front yang terbentuk di perairan Pangandaran selama tahun 2016-2018 seringnya terjadi pada musim barat dan musim peralihan 2, disajikan pada Gambar 3 hingga Gambar 5. Hal tersebut diduga dapat mempengaruhi produksi ikan tenggiri yang cukup stabil pada musim barat.

Hasil dari penelitian yang dilakukan bahwa total hasil tangkapan ikan tenggiri mengalami fluktuasi di setiap tahunnya. Penaikkan dan penurunan yang terjadi pada produksi ikan tenggiri karena dipengaruhi oleh faktor kondisi oseanografis, musim, migrasi, jenis alat tangkap dan jumlah trip armada penangkapan.

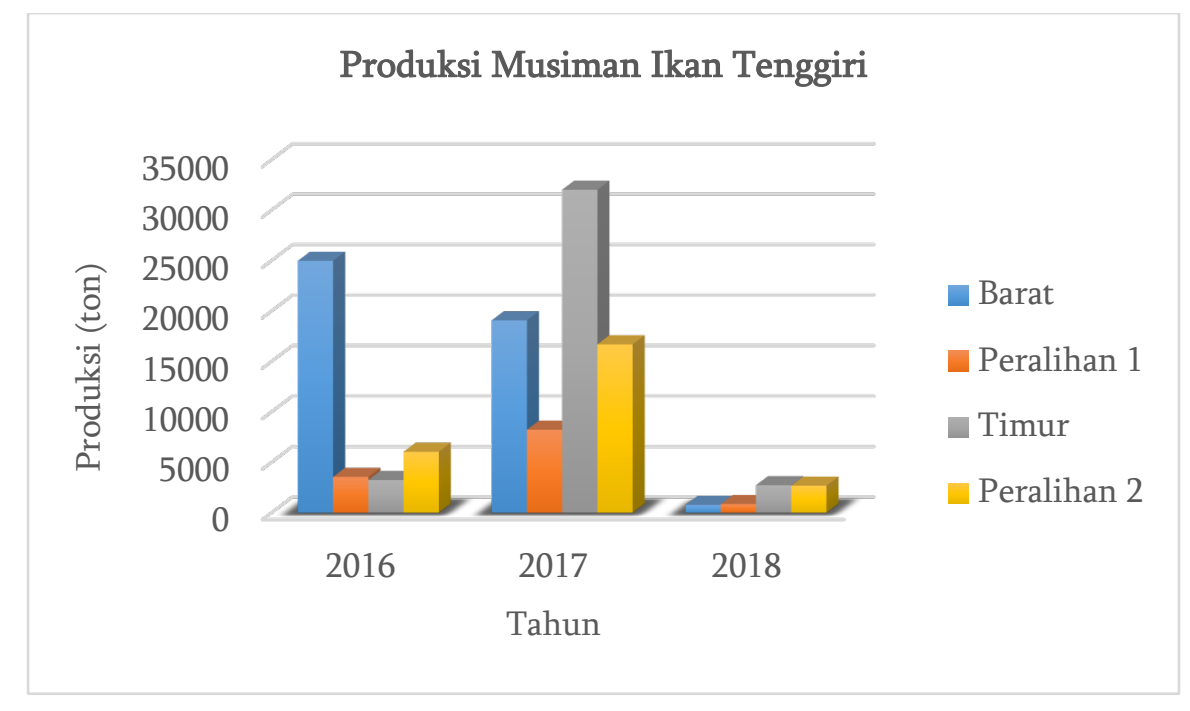

Gambar 7 Produksi musiman hasil tangkapan ikan tenggiri tahun 2016-2018

Berdasarkan hasil wawancara dikatakan bahwa nelayan di Pangandaran tidak mengklasifikasikan koordinat tangkap terhadap jenis ikan yang ditangkap, bahkan nelayan yang mencatat koordinat tangkap menggunakan GPS ketika melaut pun jarang. Biasanya yang mempunyai catatan koordinat tangkap adalah kapal-kapal dengan GT besar (>20GT) dan kapal-kapal yang berasal dari Cilacap dan sekitarnya.

Berdasarkan peta spasial pada Gambar 8, DPI tenggiri tersebar dan berada di sekitar Teluk Pangandara dan beberapa titik cukup berdekatan dengan daerah frontal. Secara umum, DPI tenggiri ini berlokasi di daerah yang cukup variatif nilai SPL-nya. Namun titik lokasi yang sangat dekat dengan daerah frontal hanya ada beberapa titik saja. Data DPI didapatkan dari hasil melaut bersama nelayan 
dari TPI Nusawiru dan TPI Cikidang. Data koordinat lokasi penangkapan ikan yang dilengkapi dengan nilai produksi khusus tenggiri pada tiap lokasi tangkap ini hanya pada dua bulan, yaitu Agustus 2018.

Volume produksi ikan tenggiri secara temporal selama tiga tahun terakhir yang didaratkan di Kabupaten Pangandaran disajikan pada Gambar 7. Hasil tangkapan tertinggi terjadi pada musim timur tahun 2017, namun produksi hasil tangkapan cenderung dan stabil pada musim barat dan musim timur. Total produksi musim barat selama tiga tahun mencapai $44.842,1 \mathrm{~kg}$ dan musim timur mencapai $38.002,85 \mathrm{~kg}$. Sedangkan total produksi musim peralihan 1 diperoleh hasil 12.654,2 $\mathrm{kg}$ dan musim peralihan 2 seberat $25.438,3 \mathrm{~kg}$.

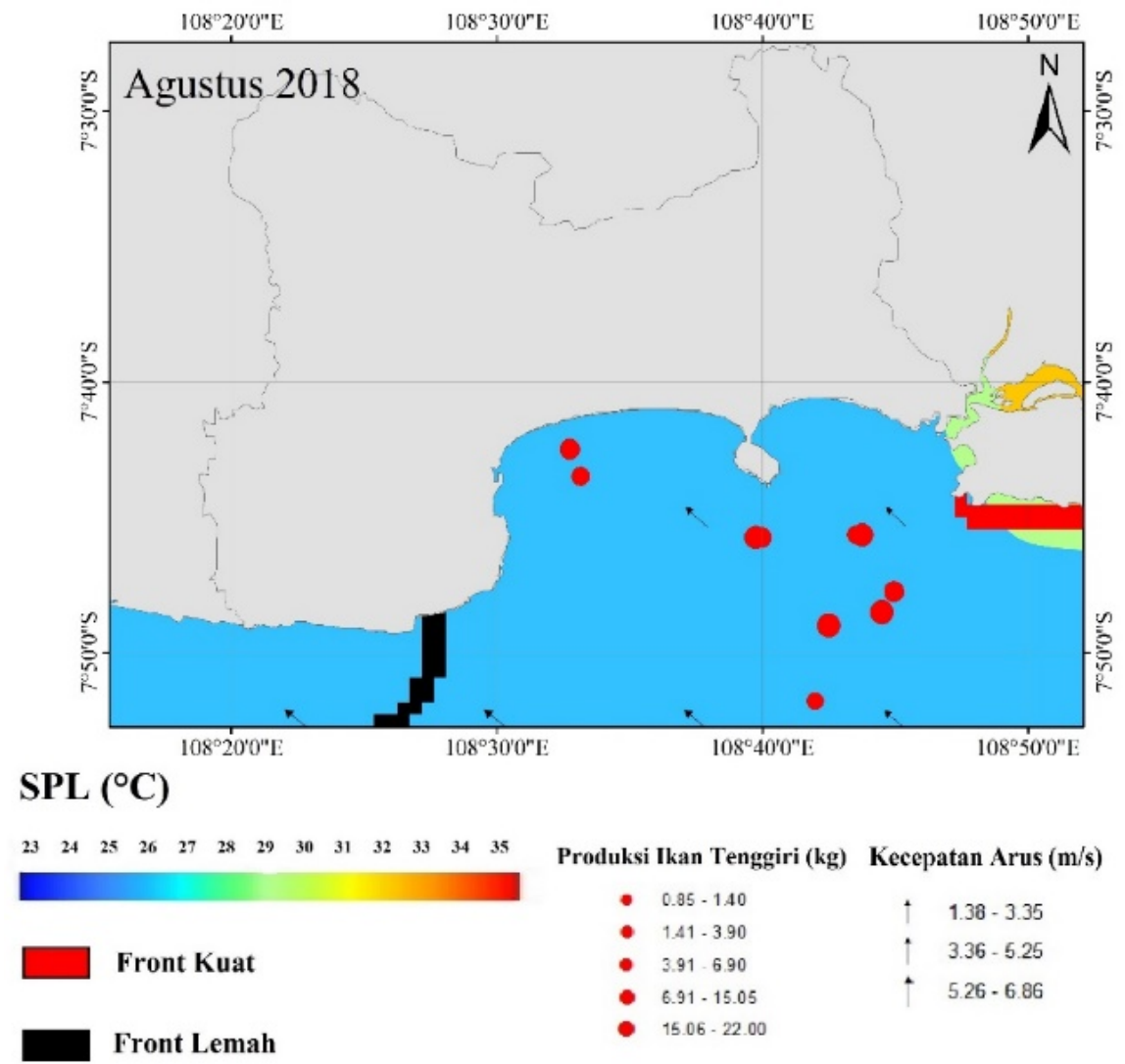

Gambar 8 Peta spasial DPI tenggiri bulan Agustus 2018

Secara umum jumlah hasil tangkapan yang didapatkan pada daerah terjadinya thermal front tidak selalu besar jika dibandigkan jumlah hasil tangkapan yang tidak berada pada kawasan thermal front. Diindikasikan wilayah penangkapan nelayan yang tidak begitu luas dikarenakan nelayan hanya menggunakan perahu berukuran 2 GT. Selain itu thermal front lebih banyak terjadi di daerah selatan Pangandaran (Samudera Hindia). Hal ini juga terdapat pada penelitian menurut Mustasim et al. (2015) menyatakan bahwa belum ditemukannya adanya pengaruh signifikan antara hasil tangkapan ikan cakalang dengan thermal front di perairan Pulau Seram.

\section{KESIMPULAN DAN SARAN}

Hasil analisis menunjukkan bahwa pada musim barat di perairan Pangandaran mendominasi pembentukkan thermal front. Banyaknya kejadian front dalam suatu perairan paling tinggi yaitu sebanyak 9 kali kejadian front dari 3 bulan pada 1 musim, yaitu perairan sekitar Teluk Pangandaran. Memiliki rata-rata luas bulanan dalam tiga tahun tertinggi di bulan Oktober (musim peralihan 2) sebesar 87,83 km², berpola tesebar di timur perairan Pangandaran saat musim barat (hujan) sedangkan untuk musim timur intensitas front jarang terlihat atau bahkan tidak ada hal itu diduga karena sedang 
musim kemarau sehingga, tidak adanya pencampuran massa air dingin dan hangat di wilayah tersebut. Secara umum persebaran thermal front mengikuti lokasi ocean mixing akibat pola pergerakan arus permukaan laut oleh angin muson.

Dalam riset ini, hal yang paling menjadi kendala adalah pengumpulan data ikan tenggiri terutama data koordinat lokasi penangkapan yang dilengkapi berat hasil tangkap khusus tenggiri di lokasi tersebut dikarenakan tidak adanya logbook penangkapan untuk nelayan Pangandaran. Maka dari itu khusus untuk wilayah Pangandaran, harus dilakukan regulasi yang baik mulai dari nelayan, Tempat Pelelangan Ikan (TPI), hingga Dinas Perikanannya. Agar datanya terekap dan bisa digunakan untuk keperluan pemerintah ataupun kaum akademisi supaya perikanan tangkap di wilayah Pangandaran semakin maju. Selain itu, diperlukan pula riset lanjutan dengan mempertimbangkan parameter oseanografi lainnya seperti klorofil-a untuk melihat pengaruh kondisi oseanografi lainnya pada ikan tenggiri.

\section{UCAPAN TERIMA KASIH}

Ucapan terimakasih ditujukan kepada kepala serta staf TPI Cikidang, nelayan di TPI Cikidang yang telah memberikan izin dan informasi selama riset. Serta semua pihak yang sudah membantu secara langsung maupun tidak langsung dalam pembuatan naskah karya ilmiah ini.

\section{DAFTAR PUSTAKA}

Ahmad, A. L., Syamsuddin, M. L., \& Purba, N. P. 2017. Kondisi Thermal front Ditinjau dari EL NINO dan ARLINDO di Perairan Selatan Jawa Timur dan Bali Pada Muson Timur. Jurnal Perikanan dan Kelautan. (1)186-191.

Angraeni, I., R.N. Safruddin \& M. Zainuddin. 2014. Analisis spasial dan temporal hasil tangkapan ikan cakalang (Katsuwonus Pelamis) dan thermal front pada musim peralihan di perairan Teluk Bone. J. IPTEKS PSP. (1): 20-27.

Cayulla, J.F. and P. Cornillon. Edge Detection Algoritm for SST Images. Journal of Atmospheric and Oceanic Technology 9(1): 67-80 (1992).

Cayulla, J.F. and P. Cornillon. Multi Image Edge Detection for SST Images. Journal of Atmospheric and Oceanic Technology 12: 821-829 (1995).

Daulay S.R., Sari T.E.Y., Usman U., dan Jhonnerrie R. 2019. Karakteristik Thermal front di Perairan Tropis Samudera Hindia Bagian Timur. Jurnal Perikanan 21 (1): 25-29.

Fadika Ulha, Aziz Rifai, Baskoro Rochaddi. 2014. Arah Dan Kecepatan Angin Musiman Serta Kaitannya Dengan Sebaran Suhu Permukaan Laut Di Selatan Pangandaran Jawa Barat. Jurnal Oseanografi. 3: $429-437$.

Hamzah, R., T. Prayogo \& W.K. Harsanugraha. 2014. Identifikasi thermal front dari data satelit Terra/ Aqua MODIS menggunakan metode single image edge detection (Studi Kasus: Perairan Utara dan Selatan Pulau Jawa). Prosiding. Seminar Nasional Penginderaan Jauh.

Hanintyo, R., S. Hadianti., R.M.P. Mahardhik., J.S. Aldino \& F. Islamy. 2015. Sebaran musiman kejadian thermal front berdasarkan citra Aqua-MODIS di WPP-RI 714, 715 dan 716. Prossiding. Seminar Nasional Penginderaan Jauh.

Hendriati, N., Suwarso., Aldrian, E., Amri, K., Andiastuti, R., Sachoemar, S.I., Wahyono, I.B.. 2005. Seasonal Variation of Pelagic Fish Catch around Java. Oceanography 18 (4), Special Issue The Indonesian Seas: $112-123$. 
Nurhayati, Atikah. 2013. Analisis Potensi Lestari Perikanan Tangkap di Kawasan Pangandaran. Jurnal Akuatika. Vol. IV No.2. Halaman 195-209.

Olson, D. B, Hitchcock, G.I., Mariano, A.J. 1994. Life on the Edge: Marine Life and Fronts. Oceanography 7 (2): 52-50.

Podesta, G. P., J. A. Browder. 1993. Exploring the association between swordfish catch rates and thermal fronts on U.S. longline grounds in the western North Atlantic. Continental Shelf Research 13: 253-277.

Safitri, M., Cahyani, S. Y., \& Putri, M. R. 2012. Variasi Arus Arlindo dan Parameter Oseanografi Di Laut Timor Sebagai Indikasi Kejadian ENSO. Jurnal Ilmu dan Teknologi Kelautan Tropis. 4(2):369-377.

Situmorang, D. M., Agustriani F., \& Fauziyah. 2017. Analisis Penetuan Musim Penangkapan Ikan Tenggiri (Scomberomorus sp.) yang Didaratkan di PPN Sungailat, Bangka. Maspari Jurnal. 10(1):81-88.

Wyrtki, K. 1962. The Upwelling in the Region between Java and Australia during the South East Monsoon. Australian Journal of Marine and Freshwater Research 13(3):217-225. 